TITLE:

\title{
Myrmecophagy in a ranid frog Rana rugosa: specialization or weak avoidance to ant eating?
}

AUTHOR(S):

Hirai, Toshiaki; Matsui, Masafumi

\section{CITATION:}

Hirai, Toshiaki ...[et al]. Myrmecophagy in a ranid frog Rana rugosa: specialization or weak avoidance to ant eating?. Zoological Science 2000, 17(4): 459-466

ISSUE DATE:

2000-05

URL:

http://hdl.handle.net/2433/65050

RIGHT:

(c) 日本動物学会 / Zoological Society of Japan 


\title{
Myrmecophagy in a Ranid Frog Rana rugosa: Specialization or Weak Avoidance to Ant Eating?
}

\author{
Toshiaki Hirai and Masafumi Matsui* \\ Graduate School of Human and Environmental Studies, Kyoto University, Sakyo-ku, Kyoto 606-8501, Japan
}

\begin{abstract}
We studied diets of an Asian ranid, Rana rugosa, inhabiting three different environments (reservoir, river shoreline, and paddy fields) in Kyoto, Japan. In all the three habitats, ants were the most frequently consumed prey, representing surprisingly similar proportions in both the frequency of occurrence $(81.9-85.7 \%)$ and the number of total prey items (56.8-59.4\%). These values are exceptionally large for Rana, and equivalent to those reported for ant specialists in other families of frogs such as dendrobatids or bufonids. However, $R$. rugosa consumed ants lower in proportions than those found in the environment, and could not be regarded as purely ant specialists. Instead, we conclude that this species tends to avoid ants more weakly than other species of Rana. Other than ants, larger prey were more and smaller ones less frequently taken in proportion to frog body size, indicating that the frog consumes ants because of its weak avoidance of these abundant potential prey.
\end{abstract}

\section{INTRODUCTION}

Frogs, in general, are generalist predators and consume a wide variety of prey in response to prey availability in the environment (Duellman and Trueb, 1986). Some frogs, however, are known to selectively feed on particular prey. Many dendrobatid and some bufonid species are myrmecophagous. These frogs are specialized for eating ants, and consume them in a higher proportion than found in surrounding environments (Toft, 1980; 1981; Lieberman, 1986). Within Dendrobatidae, suites of traits related to diet and foraging may have been a significant force driving radiation of the family at the generic level (Toft, 1995; Caldwell, 1996). Detailed studies of feeding habits in a number of frog families are needed to examine the evolution of myrmecophagy in anurans as a whole.

The family Ranidae contains more than 600 species and is distributed worldwide (Duellman and Trueb, 1986). Diets of ranid frogs have been studied by many workers from various regions of the world. Ranids are considered to be generalist predators (e.g., Houston, 1973; Premo and Atomowidjojo, 1987 ) and to change their diets in response to natural fluctuations of prey availability (Turner, 1959; Tyler and Hoestenbach, 1979; Hirai and Matsui, 1999). Ranid frogs are gape-limited predators that regulate size of their prey by gape width or body size (Kramek, 1972) and their diets change ontogenetically (Werner et al., 1995). Myrmecophagy, common in dendrobatids and bufonids, has never been reported for any species of ranid, although the family is speciose and contains morphologically and ecologically diverse species and genera. Is myrmecophagy really absent among ranid frogs?

Rana rugosa is distributed in east Asia from Japan to

\footnotetext{
* Corresponding author: FAX. 075-753-2891.

E-mail. fumi@zoo.zool.kyoto-u.ac.jp
}

northeastern China, and commonly found from city areas to montane regions. The frog occupies various habitats and breeds both in still water and in running water. Differing from the other ranids, $R$. rugosa has been reported to consume large numbers of ants (Maeda and Matsui, 1989), but this previous report is anecdotal, based on few quantitative data. In order to assess myrmecophagy in this species, we conducted an extensive diet analysis placing particular emphasis on anteating. Specifically, we examined (1) ontogenetic dietary change, (2) variation in diet among different habitats, and (3) relationships between diet composition and prey availability in the environment of the frog's habitat.

\section{MATERIALS AND METHODS}

Field work

For stomach content analyses, we collected frogs from three distinctly different environments in Kyoto, central Japan: (1) a reservoir at Iwakura $\left(35^{\circ} 06^{\prime} \mathrm{N}, 135^{\circ} 52^{\prime} \mathrm{E}\right)$ between June and August in 1996 ; (2) a shoreline of the Kiyotaki River at Kiyotaki $\left(35^{\circ} 03^{\prime} \mathrm{N}, 135^{\circ} 47^{\prime} \mathrm{E}\right)$ between June and August in 1997; (3) paddy fields at Shizuhara $\left(35^{\circ} 07^{\prime} \mathrm{N}, 135^{\circ} 52^{\prime} \mathrm{E}\right)$ from May to September in 1995 and 1996. As a result, we examined a total of 77,67 , and 16 stomachs from each population. We made each collection at night between $1800 \mathrm{hr}$ and $0200 \mathrm{hr}$ because we observed frogs more frequently at night than during the daytime.

Within two hours of capture, we anesthetized frogs in $1 \%$ solution of MS-222 (methane tricaine sulfonate) and extracted their stomach contents with forceps. Contents were preserved in $10 \%$ buffered formalin for later identification and analyses. For each frog, we recorded snout-vent length (SVL) to nearest $0.1 \mathrm{~mm}$ and toe-clipped for individual identification. After these procedures, we released frogs where they were captured.

In paddy fields, we sampled potential prey invertebrates on the Aze (slightly elevated narrow trail between adjoining rice fields) using two different techniques to estimate prey availability. To sample prey above ground, we made $1 \times 80 \mathrm{~m}$ sweeps through the air and vegeta- 
tion, $0-0.5 \mathrm{~m}$ above the ground with an insect sweep net. For sampling terrestrial prey, we directly collected all visible animals on the ground or beneath stones in a $1 \times 1 \mathrm{~m}$ plot using forceps. We collected samples before sunset $(1800 \mathrm{hr}-1900 \mathrm{hr}$, overlapping the time when frogs were active) on three days (spring: 27 May; summer: 26 July; autumn: 27 September 1995). These sampling dates largely covered the periods when frogs were actually collected. The sampled prey were killed with ethyl acetate and stored in ethylene glycol for later identification and analyses.

\section{Diet analysis}

We identified stomach contents and potential prey to the level of class or order except for Hymenoptera, which was classified into Formicidae and non-Formicidae. For holometabolous insects, larvae and adults were separated. The occurrence of plant materials or minerals were recorded for each stomach. Maximum length and width of prey, excluding antennae and cerci, were measured to the nearest $0.1 \mathrm{~mm}$ using a caliper or a calibrated ocular micrometer fitted to a dissecting microscope. For partially digested prey items, lengths $(\mathrm{L})$ were estimated by measuring widths $(\mathrm{W})$ and using predetermined length-width regressions from intact prey. Volumes of prey items were calculated by the formula for an ellipsoid (Dunham, 1983):

$$
\mathrm{V}=4 / 3 \pi(\mathrm{L} / 2)(\mathrm{W} / 2)^{2}
$$

To detect ontogenetic diet change, we examined predator-prey size relationships by regressing volumes of the largest and smallest prey in a stomach to frog SVL and calculating correlation coefficients. Only frogs with at least three prey items in the stomach were included in this analysis. In addition, we examined relationships between frog SVL and the frequency of occurrence of the major (>25.0\%) prey taxa using the reservoir population. The taxa included ants, beetles, dipterans, hemipterans, and spiders. For this analysis, we divided frogs by their SVL into size classes with intervals of $5.0 \mathrm{~mm}$, and excluded the classes consisting of less than three individuals. For these examinations, we used the data from the reservoir because it had the largest number of stomach samples and contained frogs with a broad range of SVLs.

To examine variation in diets among populations inhabiting different environments, we compared the presence or absence of the five major prey taxa mentioned above with chi-squared $2 \times 3$ contingency table test. We also tested the difference in the numeric proportion of these taxa by using $\chi^{2}$ test (Zar, 1999). The five major taxa found in the reservoir were commonly seen in stomachs of frogs from the river shoreline and the paddy fields ( $>18.0 \%$ in frequency of occurrence in all populations).

To determine the relationship between prey availability and diet composition, we calculated Kendall's rank correlation coefficients $(\tau)$, corrected for ties (Siegel, 1956) between the relative abundances of prey taxa in the habiat and their abundances in frog stomach contents. We approximated the prey availability within an area of $80 \mathrm{~m}^{2}$ by combining the total abundances of sweep and ground plot samples. In this analysis, we used only taxa that were found in both potential prey samples and the stomach contents.

Simon and Toft (1991) defined ant specialists as those frogs that consume ants in higher proportion than those found in the environment. We adopted this definition and calculated electivity indices ( $E$ of Ivlev, 1961 and $E^{*}$ of Vanderploeg and Scavia, 1979) to determine whether or not $R$. rugosa is an ant specialist. $\mathrm{E}$ is the most commomly used index, while $E^{*}$ is currently the most recommended one according to Lechowicz (1982). In this analysis, we calculated $E$ and $E^{*}$ only for ants, because these indices are vulnerable to sampling errors for prey that are rare in the diet or in the environment (Lechowicz, 1982), and relative abundance of prey taxa other than ants greatly fluctuated seasonally, thus leading to large sampling errors. Both index values deviate symmetrically from zero between -1.0 to +1.0 as a prey taxon is respectively, avoided or preferred.

\section{RESULTS}

\section{Diet composition}

We identified 1577 prey items extracted from stomachs of 72 frogs collected at the reservoir; the remaining five frogs had empty stomachs. Arthropoda contained five classes (Arachnida, Crustacea, Chilopoda, Diplopoda, and Insecta) and constituted $97.3 \%$ in number and $96.7 \%$ in volume of the total stomach contents. Insecta contained 13 orders, and constituted $91.8 \%$ in number and $75.5 \%$ in volume (Table 1 ).

Ants (Formicidae) were not only the most frequently consumed prey taxon (81.9\%), but also constituted the largest proportion in number (56.8\%)(Table 1). In volume, however, ants constituted only a minute fraction (10.8\%). Besides arthropods, gastropods, mostly lymnaeid pond snails, were present. Plant materials (plant pieces) and minerals (pebbles and dirt) were found in $19.4 \%$ and $25.0 \%$ of stomachs examined, respectively.

\section{Ontogenetic change}

As $R$. rugosa increases in body size, it consumes larger prey. There were significant positive correlations between frog SVL and volumes of the largest and smallest prey ingested (Fig. 1; rmin=0.561, $P<0.01 ; r \max =0.287, P<0.05 ; \mathrm{n}=71$ ). Examination of the relationships between frog SVL and the frequency of occurrence of major prey taxa revealed that beetles with generally large body size exhibited a significantly positive correlation to SVL (Fig. $2 b ; r=0.767, P<0.05$ ), but generally small-sized dipterans had a significantly negative correlation (Fig. 2c; $r=-0.776, P<0.05$ ). On the other hand, ants were consumed frequently regardless of frog body size, and their occurrence did not significantly correlate with SVL (Fig. 2a; $r=-0.230$, NS). Hemipterans and spiders also showed no significant correlations (Fig. 2d, e; $r=0.753, r=0.675$, respectively, both NS).

\section{Variation among habitats}

Ants were frequently consumed in all three habitats (Table 1). The frequency of occurrence of ants did not significantly differ among the habitats $\left(\chi^{2}\right.$ test, $\left.\chi^{2}=0.84, \mathrm{df}=2, P>0.05\right)$. By contrast, beetles were consumed significantly more often in the paddy fields $\left(\chi^{2}=9.00, \mathrm{df}=2, P<0.05\right)$. Ants were numerically the most dominant in all the habitats, and values did not differ significantly among the habitats $\left(\chi^{2}=0.93, \mathrm{df}=2, P>0.05\right)$. The next largest proportion was occupied by beetles in the paddy fields, but by dipterans in the reservoir and the river shoreline; the values differed significantly among the habitats (beetles: $\chi^{2}=94.37, \mathrm{df}=2$; dipterans: $\chi^{2}=16.88, \mathrm{df}=2, P<0.01$ for both). The numeric proportions of hemipterans and spiders did not differ significantly among the habitats (hemipterans: $\chi^{2}=94.37, \mathrm{df}=2$; spiders: $\chi^{2}=16.88, \mathrm{df}=2, P>0.05$ for both). In volume, the largest proportion was occupied by beetles in both the river shoreline and the reservoir, but by beetle larvae in the paddy fields. Ants were represented volumetrically by $13.2 \%$ on the river shoreline, $4.1 \%$ in the paddy fields, and $10.8 \%$ in the reservoir. 
Table 1. Dietary comparison of $R$. rugosa from the reservoir (1577 prey from 72 individuals, total volume $10902.4 \mathrm{~mm}^{3}$ ), the river shoreline (431 prey from 53 individuals, total volume $5691.5 \mathrm{~mm}^{3}$ ), and the paddy fields (262 prey from 14 individuals, total volume $4323.23 \mathrm{~mm}^{3}$ ).

\begin{tabular}{|c|c|c|c|c|c|c|c|c|c|}
\hline \multirow{2}{*}{ Prey taxa } & \multicolumn{3}{|c|}{$\begin{array}{c}\text { Frequency of } \\
\text { occurrence (\%) }\end{array}$} & \multicolumn{3}{|c|}{$\begin{array}{c}\text { Numeric } \\
\text { proportion (\%) }\end{array}$} & \multicolumn{3}{|c|}{$\begin{array}{c}\text { Volumetric } \\
\text { proportion (\%) }\end{array}$} \\
\hline & $\begin{array}{l}\text { Reser- } \\
\text { voir }\end{array}$ & $\begin{array}{l}\text { Shore- } \\
\text { line }\end{array}$ & $\begin{array}{l}\text { Paddy } \\
\text { fields }\end{array}$ & $\begin{array}{l}\text { Reser- } \\
\text { voir }\end{array}$ & $\begin{array}{c}\text { Shore- } \\
\text { line }\end{array}$ & $\begin{array}{l}\text { Paddy } \\
\text { fields }\end{array}$ & $\begin{array}{l}\text { Reser- } \\
\text { voir }\end{array}$ & $\begin{array}{l}\text { Shore- } \\
\text { line }\end{array}$ & $\begin{array}{l}\text { Paddy } \\
\text { fields }\end{array}$ \\
\hline \multicolumn{10}{|l|}{ Insecta } \\
\hline \multicolumn{10}{|l|}{ Hymenoptera } \\
\hline Formicidae & 81.9 & 84.9 & 85.7 & 56.8 & 59.4 & 56.9 & 10.8 & 13.2 & 4.1 \\
\hline non-Formicid & 8.3 & 7.6 & 21.4 & 0.4 & 0.9 & 1.9 & 0.7 & 4.7 & 0.5 \\
\hline larvae & 5.6 & 1.9 & 7.1 & 0.3 & 0.2 & 0.4 & 1.2 & 0.6 & 0.2 \\
\hline Coleoptera & 45.8 & 41.5 & 85.7 & 3.8 & 7.7 & 19.5 & 17.3 & 20.9 & 9.9 \\
\hline larvae & 12.5 & 17.0 & 7.1 & 1.1 & 3.5 & 1.5 & 3.0 & 0.9 & 32.7 \\
\hline Diptera & 75.0 & 47.2 & 50.0 & 15.0 & 12.5 & 5.7 & 4.2 & 4.9 & 1.1 \\
\hline larvae & 22.2 & 7.6 & 14.3 & 5.6 & 1.2 & 0.8 & 1.9 & 1.3 & 4.9 \\
\hline Lepidoptera & 15.3 & 3.8 & - & 0.9 & 0.5 & - & 4.4 & 1.1 & - \\
\hline larvae & 18.1 & 11.3 & 14.3 & 1.2 & 1.6 & 1.5 & 22.7 & 23.1 & 12.5 \\
\hline Trichoptera & 1.4 & - & - & 0.1 & - & - & $<0.1$ & - & - \\
\hline Neuroptera & 6.9 & - & - & 0.3 & - & - & 0.4 & - & - \\
\hline larvae & 8.3 & 9.4 & - & 0.4 & 2.3 & - & 0.8 & 1.7 & - \\
\hline Hemiptera & 38.9 & 18.9 & 28.6 & 4.1 & 2.8 & 2.3 & 4.4 & 7.3 & 2.3 \\
\hline Dermaptera & - & 1.9 & - & - & 0.2 & - & - & 1.1 & - \\
\hline Orthoptera & 6.9 & 1.9 & 7.1 & 0.4 & 0.2 & 0.4 & 3.1 & 0.7 & 0.1 \\
\hline Plecoptera & 1.4 & - & - & 0.1 & - & - & $<0.1$ & - & - \\
\hline Odonata & 1.4 & 1.9 & - & 0.1 & 0.2 & - & 0.6 & 3.0 & - \\
\hline larvae & - & 1.9 & - & - & 0.2 & - & - & 3.9 & - \\
\hline Thysanoptera & 1.4 & - & - & 0.1 & - & - & $<0.1$ & - & - \\
\hline Collembola & 11.1 & 5.7 & 7.1 & 1.0 & 1.6 & 0.4 & $<0.1$ & 0.2 & $<0.1$ \\
\hline Protura & 2.8 & - & - & 0.2 & - & - & $<0.1$ & - & - \\
\hline \multicolumn{10}{|l|}{ Arachnida } \\
\hline Araneae & 26.4 & 20.8 & 28.6 & 1.7 & 2.6 & 1.9 & 3.2 & 1.4 & 1.4 \\
\hline Opiliones & - & - & - & - & - & - & - & - & - \\
\hline Acarina & 4.2 & - & - & 0.2 & - & - & $<0.1$ & - & - \\
\hline Isopoda & 5.6 & 5.7 & 7.1 & 1.5 & 0.7 & 0.4 & 8.8 & 4.8 & 0.2 \\
\hline Decapoda & 1.4 & 5.7 & - & 0.1 & 0.7 & - & 2.2 & 4.8 & - \\
\hline Amphipoda & - & 1.9 & - & - & 0.5 & - & - & 0.4 & - \\
\hline Chilopoda & 2.8 & - & - & 0.1 & - & - & 0.3 & - & - \\
\hline Diplopoda & 20.8 & 1.9 & 42.9 & 1.9 & 0.2 & 3.8 & 6.7 & 0.1 & 6.3 \\
\hline Gastropoda & 25.0 & 1.9 & 21.4 & 2.7 & 0.2 & 1.2 & 3.3 & 0.2 & 0.8 \\
\hline Oligochaeta & - & - & 21.4 & - & - & 1.5 & - & - & 23.2 \\
\hline Plant materials & 19.4 & 30.2 & 71.4 & - & - & - & - & - & - \\
\hline Minerals & 25.0 & 39.6 & 42.9 & - & - & - & - & - & - \\
\hline
\end{tabular}

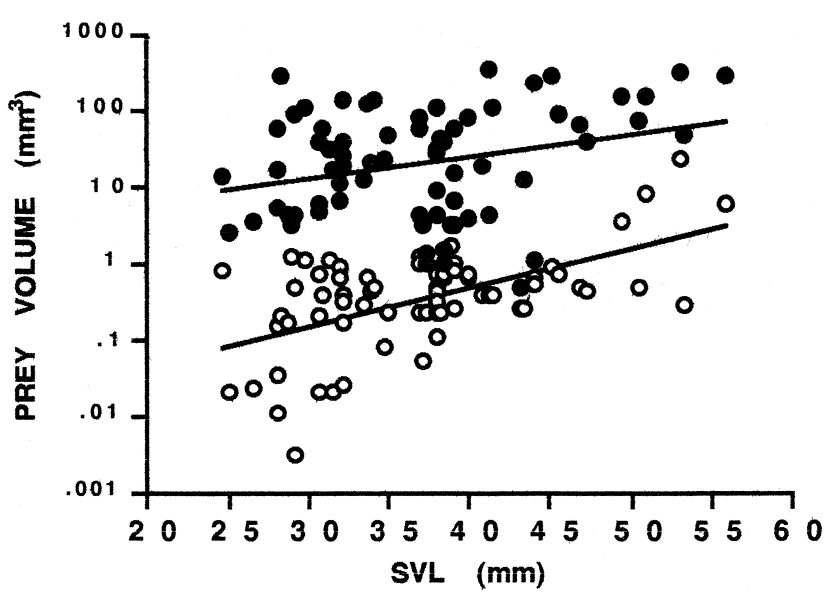

Fig. 1. Relationships between frog SVL and minimum $(\bigcirc)$ and maximum (1) volumes of prey in stomach contents.

\section{Prey selection}

Dipterans and hemipterans were abundant prey taxa in the sweep samples, whereas ants were the most abundant prey taxon in the ground plot samples. Rana rugosa consumed prey animals occurring both above ground and on the ground. The relative abundances of prey taxa in the habitat were significantly correlated with their abundances in frog stomach contents $(\tau=0.470, P<0.05$; Table 2$)$.

The proportion of ants in the environment (81.3\%) outweighed that found in the frog diet $(56.9 \%)$, and both $E$ $(-0.18)$ and $E^{*}(-0.50)$ indicated that $R$. rugosa avoided ants.

\section{DISCUSSION}

Regardless of differences in body size or habitat environments, $R$. rugosa proved to consume ants very frequently, and the prey represented surprisingly similar proportions in the frequency of occurrence (81.9-85.7\%) and in number 


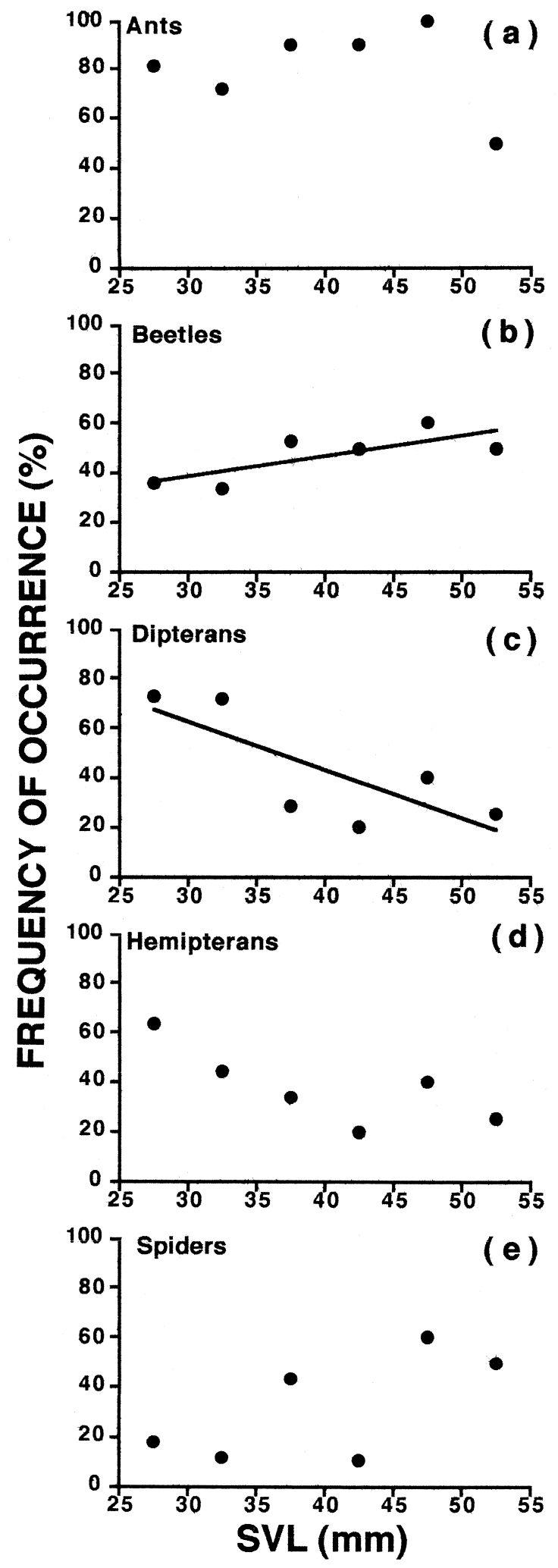

Fig. 2. Relationships between frog SVL and the frequency of occurrence of major prey taxa.

(56.8-59.4\%) among the three populations studied. From these large proportions of ants, $R$. rugosa may be viewed as an ant specialist. However, Simon and Toft (1991) suggested that ant specialists should consume ants higher in proportions than those found in the environment. Since there is no other definition for ant specialisits, we followed Simon and Toft (1991). Such a definition did not hold for $R$. rugosa, and this species is not regarded as a true ant specialist. Even so, the large proportion of ants taken by $R$. rugosa (56.8-59.4\%) is within the range for those species that have been described as ant specialists (52-99\%; Toft, 1980, 1981; Lieberman, 1986).

In fact, the proportion of ants was larger in the environment than in the frog diet, and both electivity indices ( $E$ and $E^{*}$ ) indicated that $R$. rugosa avoided ants. However, ant avoidance in $R$. rugosa was distinctively weaker than in another rice field dwelling ranid, $R$. nigromaculata $\left(E=-0.60, E^{*}=-0.86\right.$; Hirai and Matsui, unpubl. data). This weak avoidance to ants by $R$. rugosa may result in its food habit to take prey in response to their relative abundance in the environment where ants were the most abundant.

According to available dietary reports from various areas of the world, ranid frogs are grouped into generalist predators that consume a wide variety of prey organisms, responding to prey availability in the environment (e.g., Turner, 1959; Houston, 1973; Premo and Atomowidjojo, 1987). Rana rugosa also consumed a various kind of prey items, but ants made up a prominently large proportion in number (56.8-59.4\%) that has never been reported for Rana (see Appendix 1). For example, in the diet of $R$. limnocharis and $R$. nigromaculata, that are often found syntopic with $R$. rugosa, ants represent at most 13.5-27.9\% and 15.1-20.3\%, respectively (Liu and Chen, 1933; Berry, 1965; Mohanty-Hejmadi and Acharya, 1982; Hirai and Matsui, 1999, see Appendix 1). Even the largest proportional value of ants in Rana that has ever been reported is only $35.0 \%$ ( $R$. blythi: Inger and Greenberg, 1966), and therefore, it is clear that values of $56.8-59.4 \%$ found in $R$. rugosa are exceptionally large for Rana. This result suggests that $R$. rugosa has very peculiar feeding habits that are different from the other ranid frogs so far studied. This is probably due to weak ant avoidance by this species as mentioned above. Thus, we could confirm the validity of the anecdotal remarks that $R$. rugosa eats markedly numerous ants (Maeda and Matsui, 1989).

An animal must maintain a positive energy budget to grow, reproduce, and survive periods of inactivity. Optimal foraging theory suggests that larger animals should select large prey and overlook small prey which is too low to warrant energy involved in their pursuit and consumption (Schoener, 1979). In fact, a hylid frog, Pseudacris triseriata, excludes smaller prey from its diets as it ingests increasingly larger prey with its growth (Christian, 1982). Similar results have been obtained in $R$. nigromaculata; ants were important prey for metamorphosed juveniles of this species (SVL $<40 \mathrm{~mm}$ ), and represent $45 \%$ in their diets. However, subadults or adults (SVL $\geq 40$ $\mathrm{mm}$ ) became less incorporated ants into their diets, and the proportion of ants decreased to less than 20\% (Hirai and Matsui, 1999).

Rana rugosa also consumed larger prey such as beetles 
Table 2. Comparison of the relative abundances of prey taxa in the habitat with their abundances in the frog diet. See text for total abundances of prey taxa in combined samples.

\begin{tabular}{|c|c|c|c|c|c|c|c|}
\hline \multirow{2}{*}{ Prey taxa } & \multicolumn{2}{|c|}{ Sweep } & \multicolumn{2}{|c|}{ Ground plot } & \multicolumn{2}{|c|}{ Combined } & \multirow{2}{*}{$\frac{\text { Diet }}{\%}$} \\
\hline & $\mathrm{N}$ & $\%$ & $\mathrm{~N}$ & $\%$ & $\mathrm{~N}$ & $\%$ & \\
\hline \multicolumn{8}{|l|}{ Insecta } \\
\hline \multicolumn{8}{|l|}{ Hymenoptera } \\
\hline Formicidae & 179 & 14.2 & 499 & 83.0 & 40099 & 81.3 & 56.9 \\
\hline non-Formicid & 37 & 2.9 & - & - & 37 & $<0.1$ & 1.9 \\
\hline larvae & 5 & 0.4 & - & - & 5 & $<0.1$ & 0.4 \\
\hline Coleoptera & 149 & 11.8 & 21 & 3.5 & 1829 & 3.7 & 19.5 \\
\hline larvae & 8 & 0.6 & 2 & 0.3 & 168 & 0.3 & 1.5 \\
\hline Diptera & 351 & 27.8 & - & - & 351 & 0.7 & 5.7 \\
\hline larvae & - & - & - & - & - & - & 0.8 \\
\hline Lepidoptera & 14 & 1.1 & - & - & 14 & $<0.1$ & - \\
\hline larvae & 10 & 0.8 & - & - & 10 & $<0.1$ & 1.5 \\
\hline Neuroptera & 2 & 0.2 & - & - & 2 & $<0.1$ & - \\
\hline Hemiptera & 327 & 25.9 & 4 & 0.7 & 647 & 1.3 & 2.3 \\
\hline Dermaptera & - & - & 7 & 1.2 & 560 & 1.1 & - \\
\hline Orthoptera & 91 & 7.2 & 1 & 0.2 & 171 & 0.4 & 0.4 \\
\hline Collembola & - & - & - & - & - & - & 0.4 \\
\hline \multicolumn{8}{|l|}{ Arachnida } \\
\hline Araneae & 89 & 7.1 & 32 & 5.3 & 2649 & 5.4 & 1.9 \\
\hline Acarina & 2 & 0.2 & - & - & 2 & $<0.1$ & - \\
\hline Isopoda & - & - & 21 & 3.5 & 1680 & 3.4 & 0.4 \\
\hline Diplopoda & - & - & 10 & 1.7 & 800 & 1.6 & 3.8 \\
\hline Gastropoda & - & - & - & - & - & - & 1.2 \\
\hline Oligochaeta & - & - & 4 & 0.7 & 320 & 0.7 & 1.5 \\
\hline
\end{tabular}

more frequently and smaller prey such as dipterans less frequently with the increase of body size. However, ants were constantly consumed in a high frequency regardless of body size, and we could not detect ontogenetic change in ant consumption. Therefore, we presume that $R$. rugosa feeds on ants because it does not strongly avoid these most abundant potential prey in the habitat.

Prey availability is proved as one of the most important factors to determine what frogs eat (Labanick, 1976; Galatti, 1992; Hirai and Matsui, 1999). In generalist predators such as ranids, their diet compositions are known to vary among habitats. For example, R. catesbeiana inhabiting the pond consumes mainly insects, but the frog eats mostly crustaceans such as crayfish in the stream (Tyler and Hoestenbach, 1979). Similarly, $R$. cancrivora eats mostly crustaceans in brackish water habitats, but insects in fresh water habitats (Elliott and Karunakaran, 1974). We examined the diets of $R$. rugosa from three environmentally different habitats, and also detected differences in frequency of occurrence of beetles and in numeric proportions of beetles and dipterans among different habitats. Therefore, the diets of $R$. rugosa were judged to be influenced by prey availability in the habitats. However, differences were not detected for ants in either the frequency of occurrence or the numeric proportion; ants remained dominant in the diet in surprisingly similar proportions in all the three habitats (reservoir $=56.8 \%$, shoreline $=59.4 \%$ : paddy fields $=56.9 \%$ ) despite their small volumetric contributions (4.1$13.2 \%$ ). This result appears to conform to the presumption that $R$. rugosa shows only weak avoidance to ants.

Ant specialists such as dendrobatids are known to have toxic skin secretions that serve a defensive role. Daly (1995) and Daly et al. (1994) suggested that the toxic skin secretions were sequestered from their dietary sources. Since their diets principally consisted of ants, Toft (1995) and Caldwell (1996) suggested that anti-predator tactics were highly correlated with ant specialized diets. Rana rugosa is also presumed to have distasteful skin secretions by which the species is rarely predated by snakes in nature (Mori and Moriguchi, 1988). Actually, avoidance of $R$. rugosa by snakes has been demonstrated experimentally, by offering this species and Hyla japonica to Elaphe quandrivirgata, a generalist predator (Mori, 1989). From these knowledge, myrmecophagy by $R$. rugosa may also be correlated with predator defence in this species.

Feeding patterns of myrmecophagous dendrobatids were shown to be correlated with not only anti-predator tactics but also foraging strategy, morphology, and physiology (Toft, 1980, 1981). More detailed investigations of feeding habits in R. rugosa may help us to understand the ecological significance of weak ant avoidance by this species.

\section{ACKNOWLEDGMENTS}

We thank K. Araya for help in identifying insects. We also thank anonymous reviewers for providing useful comments on an early version of the manuscript.

\section{REFERENCES}

Berry PY (1965) The diet of some Singapore Anura (Amphibia). Proc Zool Soc Lond 144: 163-174

Blackith RM, Speight MCD (1974) Food and feeding habits of the 
frog Rana temporaia in bogland habitats in the West of Ireland. $J$ Zool Lond 172: 67-79

Caldwell JP (1996) The evolution of myrmecophagy and its correlates in poison frogs (family Dendrobatidae). J Zool Lond 240: 75-101

Christian KA (1982) Changes in the food niche during postmetamorphic ontogeny of the frog Pseudacris triseriata. Copeia 1982: $73-80$

Corse WA, Metter DE (1980) Economics, adult feeding and larval growth of Rana catesbeiana on a fish hatchery. J Herpetol 14: 231-238

Daly JW (1995) The chemistry of poisons in amphibian skin. Proc Nat Acad Sci USA 92: 9-13

Daly JW, Secunda SI, Garraffo HM, Spande TF, Wisnieski A, Cover JF Jr (1994) An uptake system for dietary alkaloides in poison frogs (Dendrobatidae). Toxicon 32: 657-663

Das I (1996) Folivory and seasonal changes in diet in Rana hexadactyla (Anura: Ranidae). J Zool Lond 238: 785-794

Duellman WE, Trueb L (1986) Biology of Amphibians. McGraw-Hill, New York

Dunham AE (1983) Realized niche overlap, resource abundance, and intensity of interspecific competition. In "Lizard Ecology" Ed by RB Huey, ER Pianka, TW Schoener, Harvard Univ Press, Cambridge, pp 261-280

Elliott AB, Karunakaran L (1974) Diet of Rana cancrivora in fresh water and brackish water environments. J Zool Lond 174: 203215

Frederick RG, Collette BB (1959) Distributional and biological notes on the Nebraskka (sic) herpetofauna. Herpetologica 15: 141143

Galatti U (1992) Population biology of the frog Leptodactylus pentadactylus in a central Amazonian rainforest. J Herpetol 26: 23-31

Hamilton WJ Jr (1948) The food and feeding behavior of the green frog, Rana clamitans Latreille, in New York State. Copeia 1948: 203-207

Hedeen SE (1972) Food and feeding behavior of the mink frog, Rana septentrionalis Baird, in Minnesota. Am Midl Nat 88: 291-300

Hirai T, Matsui M (1999) Feeding habits of the pond frog, Rana nigromaculata, inhabiting rice fields in Kyoto, Japan. Copeia 1999: 940-947

Houston WWK (1973) The food of the common frog, Rana temporaria, on high moorland in northern England. J Zool Lond 171: 153165

Inger RF, Greenberg B (1966) Ecological and competitive relations among three species of frogs (genus Rana). Ecology 47: 746759

Inukai T (1925) Habits of frogs especially the food habits. SapporoNoringakkaihou. 16: 277-286

Ivlev VS (1961) Experimental Ecology of the Feeding of Fishes. Yale Univ Press, Connecticut

Jenssen TA, Klimstra WD (1966) Food habits of the green frog Rana clamitans in southern Illinois. Am Midl Nat 76: 169-182

Khan MS (1973) Food of tiger frog, Rana tigerina Daudin. Biologia (Lahore) 19: 93-107

Kilby JD (1945) A biological analysis of the food and feeding habits of two frogs, Hyla cinerea cinerea and Rana pipiens sphenocephala. Quart J Florida Acad Sci 8: 71-104

Korschgen LJ, Moyle DL (1976) Food habits of the bullfrog in central Missouri farm ponds. Am Midl Nat 54: 332-341

Kramek WC (1972) Food of the frog Rana septentrionalis in New York. Copeia 1972: 390-392

Labanick GM (1976) Prey availability, consumption and selection in the cricket frog, Acris crepitans (Amphibia, Anura, Hylidae). J Herpetol 10: 293-298

Lamb T (1984) The influence of sex and breeding condition on microhabitat selection and diet in the pig frog Rana grylio. Am Midl Nat
111: $311-318$

Lechowicz MJ (1982) The sampling characteristics of electivity indices. Oecologia 52: 22-30

Licht LE (1986) Food and feeding behavior of sympatric red-legged frogs, Rana aurora, and spotted frogs, Rana pretiosa, in southwestern British Columbia. Can Field-Nat 100: 22-31

Lieberman SS (1986) Ecology of the leaf litter herpetofauna of a Neotropical rain forest: La Selva, Costa Rica. Acta Zool Mex 15: 172

Linzey DW (1967) Food of the frog, Rana pipiens, in central New York. Herpetologica. 23: 11-17

Liu C, Chen K (1933) Analysis of the stomach contents of two species of frogs (Rana limnocharis and Rana nigromaculata) in the vicinity of Kashing with special reference to insects. Yb Bur Ent Chekiang Prov 1933: 183-191

Loman J (1979) Food, feeding rates and prey size selection in juvenile and adult frogs, Rana arvalis Nilss. and $R$. temporaria L. Ekol Polska 27: 581-601

Mckamie JA, Gary AH (1947) A comparison of spring food habits of the bull frog, Rana catesbeiana, in three habitats of central Arkansas. Southwest Nat 25: 107-111

Maeda N, Matsui M (1989) Frogs and Toads of Japan. Bun-ichi Sogo Shuppan, Tokyo.

Miller JD (1977) Observations on the diets of Rana pretiosa, Rana pipiens and Bufo boreas from Western Montana. Northwest Sci 52: $243-249$

Mohanty-Hejmadi P, Acharya BK (1982) Observation of food habits of six species of Indian frogs. J Bombay Nat Hist Soc 79: 120124

Moore JE, Strickland EH (1954) Notes on the food of three species of Alberta amphibians. Am Midl Nat 52: 221-224

Mori, A. (1989). Behavioral responses to an unpalatable prey, Rana rugosa (Anura: Amphibia), by newborn Japanese striped snakes, Elaphe quadrivirgata. In "Current Herpetology in EAST ASIA" Ed by M Matsui, T Hikida, RC Goris, Herpetol. Soc. Kyoto, Japan, pp 459-471

Mori A, Moriguchi $H$ (1988) Food habits of the snakes in Japan: A critical review. The Snake 20: $98-113$

Okochi I, Katsuren S (1989) Food habits in four species of Okinawan frogs. In "Current Herpetology in EAST ASIA" Ed by M Matsui, T Hikida, RC Goris, Herpetol. Soc. Kyoto, Japan, pp 405-412

Pilorge T (1982) The diets of Lacerta vivipara and Rana temporaria in two sympatric populations of Puy-de Dôme, France. AmphibReptilia 3: 27-32

Premo DB, Atomowidjojo AH (1987) Dietary patterns of the crab eating frog Rana cancrivora in west Java. Herpetologica 43: 1-6

Ramirez J, Vogt RC, Villarreal-Benitez JL (1998) Population biology of a neotropical frog (Rana vaillanti). J Herpetol 32: 338-344

Savage RM (1961) The Ecology and Life History of the Common Frog. Pitman and Sons, London

Schoener TW (1979) Generality of the size-distance relation in models of optimal foraging. Am Nat 114: 902-914

Siegel S (1956) Nonparametric Statistics for the Behavioral Science. McGraw-Hill, New York

Simon MP, Toft CA (1991) Diet specialization in small vertebrates: mite eating in frogs. Oikos 61: 263-278

Stewart MM, Sandison P (1972) Comparative food habits of sympatric mink frogs, bullfrogs, and green frogs. J Herpetol 6: 241-244

Toft CA (1980) Feeding ecology of thirteen syntopic species of anurans in a seasonal tropical environment. Oecologia 45: 131-141

Toft CA (1981) Feeding ecology of Panamanian litter anurans: Patterns in diet and foraging mode. J Herpetol 15: 139-144

Toft CA (1995) Evolution of diet specialization in poison-dart frogs (Dendrobatidae). Herpetologica 51: 202-216

Turner FB (1959) An analysis of the feeding habits of Rana p. pretiosa in Yellowstone Park, Wyoming. Am Midl Nat 61: 403-413

Tyler JD, Hoestenbach RD Jr (1979) Differences in foods of bullfrogs 
(Rana catesbeiana) from pond and stream habitats in southwestern Oklahoma. Southwest Nat 24: 33-38

Tyler MJ (1958) On the diet and feeding habits of the edible frog (Rana esculenta L.). Proc Zool Soc Lond 131: 583-595

Vanderploeg HA, Scavia D (1979) Calculation and use of selectivity coefficients of feeding: zooplankton grazing. Ecol Model 7: 135149

Werner EE, Wellborn GA, McPeek MA (1995) Diet composition in postmetamorphic bullfrogs and green frogs: Implications for interspecific predation and competition. J Herpetol 29: 600-607
Whitaker JO Jr (1962) Habitat and food of mouse trapped young Rana pipiens and Rana clamitans. Herpetologica 17: 173-179

Whitaker JO Jr, Cros SP, Skovlin JM (1983) Food habits of the spotted frog Rana pretiosa from managed sites in Grant Country, Oregon, USA. Northwest Sci 57: 147-154

Zar JH (1999) Biostatistical Analysis. 4th ed, Prentice-Hall, New Jersey

(Received September 2, 1999 / Accepted November 11, 1999)

\section{Appendix 1}

Published accounts of ant-eating in the genus Rana. Abbreviations: $F=$ frequency of occurrence; $N=$ numeric proportion; V=volumetric proportion.

\begin{tabular}{|c|c|c|c|c|c|c|c|c|}
\hline \multirow{2}{*}{ Species } & \multirow{2}{*}{$\begin{array}{l}\text { Size }(\mathrm{mm}) \\
\quad \text { or sex }\end{array}$} & \multicolumn{3}{|c|}{ Proportion (\%) } & \multicolumn{2}{|c|}{ Sample size } & \multirow{2}{*}{ Locality } & \multirow{2}{*}{ Authority } \\
\hline & & $\mathrm{F}$ & $\mathrm{N}$ & V & Frog & Prey & & \\
\hline \multirow[t]{2}{*}{ R. arvalis } & $<26$ & - & $<10^{*}$ & - & $86-110$ & - & Sweden & Loman, 1979 \\
\hline & $26-37$ & - & $<5^{\star}$ & - & 45-99 & - & Sweden & Loman, 1979 \\
\hline \multirow[t]{3}{*}{ R. aurora } & $28-33$ & 10.3 & 1.5 & - & 78 & 542 & Canada & Licht, 1986 \\
\hline & $>40$ & 3.8 & 0.6 & - & 26 & 180 & Canada & Licht, 1986 \\
\hline & - & 8.7 & 1.2 & - & 104 & 722 & Canada & Licht, 1986 \\
\hline R. blythi & $<160$ & 35 & 35 & - & 235 & 525 & Sarawak & Inger and Greenberg, 1966 \\
\hline R. breviceps & $31-44$ & - & 3.2 & - & 25 & 125 & India & Mohanty-Hejmadi and Acharya, 1982 \\
\hline \multirow[t]{4}{*}{ R. cancrivora } & Male & 3.4 & 0.9 & $<0.1$ & 219 & 320 & Java & Premo and Atomowidjojo, 1987 \\
\hline & Female & 4.2 & 1.5 & $<0.1$ & 258 & 273 & Java & Premo and Atomowidjojo, 1987 \\
\hline & $50-88$ & 26 & - & - & 19 & - & Singapore & Elliott and Karunakaran, 1974 \\
\hline & $59-100$ & 50 & - & - & 13 & - & Singapore & Elliott and Karunakaran, 1974 \\
\hline \multirow[t]{8}{*}{ R. catesbeiana } & - & 0.0 & - & 0.0 & 139 & - & Arkansas & McKamie and Gary, 1947 \\
\hline & - & 0.9 & - & + & 455 & - & Missouri & Korschgen and Moyle, 1976 \\
\hline & - & + & - & + & - & - & New York & Stewart and Sandison, 1972 \\
\hline & - & $1.5^{*}$ & - & $2.0^{*}$ & 415 & - & Oklahoma & Tyler and Hoestenbach, 1979 \\
\hline & - & $2.0^{*}$ & - & $0.5^{\star}$ & 49 & - & Oklahoma & Tyler and Hoestenbach, 1979 \\
\hline & - & $0.2-0.3^{*}$ & - & - & 1325 & - & Missouri & Corse and Metter, 1980 \\
\hline & - & - & $0-3.5$ & $0-2.1$ & - & 114 & Michigan & Werner et al., 1995 \\
\hline & - & - & 5.0 & 4.2 & - & 32 & Michigan & Werner et al., 1995 \\
\hline \multirow[t]{7}{*}{ R. clamitans } & $27-97$ & $4.6^{*}$ & - & $7.4^{*}$ & 434 & - & New York & Hamilton, 1948 \\
\hline & $60-97$ & $16.5^{\star}$ & - & $6.9^{*}$ & 85 & - & New York & Hamilton, 1948 \\
\hline & $27-58$ & - & - & $7.5^{*}$ & 31 & - & New York & Whitaker, 1962 \\
\hline & - & $27.8^{*}$ & - & $8.0^{*}$ & 475 & - & Illinois & Jenssen and Klimstra, 1966 \\
\hline & - & 0 & - & 0 & - & - & New York & Stewart and Sandison, 1972 \\
\hline & - & - & $2.8-12.5$ & $1.8-8.6$ & 116 & - & Michigan & Werner et al., 1995 \\
\hline & - & - & 7.3 & 1.0 & 16 & - & Michigan & Werner et al., 1995 \\
\hline R. cyanophlyctis & $27-65$ & - & 3.4 & - & 25 & 71 & India & Mohanty-Hejmadi and Acharya, 1982 \\
\hline \multirow[t]{2}{*}{ R. esculenta } & $22-29$ & - & 2.3 & - & 266 & 16 & France & Tyler, 1958 \\
\hline & $45-104$ & - & 5.2 & - & 459 & 47 & France & Tyler, 1958 \\
\hline R. grylio & - & 1.6 & 1.1 & 0.1 & 122 & 177 & Georgia & Lamb, 1984 \\
\hline \multirow[t]{3}{*}{ R. hexadactyla } & $15-30$ & - & - & 0 & 5 & - & India & Das, 1996 \\
\hline & $30-42.6$ & - & - & 0 & 12 & - & India & Das, 1996 \\
\hline & $>42.6$ & - & - & $<0.1$ & 444 & - & India & Das, 1996 \\
\hline R. holsti & $60-120$ & - & $0.0-1.2$ & $0.0-9.1$ & 6 & 15 & Japan & Okochi and Katsuren, 1989 \\
\hline R. ibanorum & $<130$ & 12 & 17 & - & 50 & 131 & Sarawak & Inger and Greenberg, 1966 \\
\hline R. ishikawae & $50-100$ & - & $0.0-1.6$ & 0.0 & 4 & 14 & Japan & Okochi and Katsuren, 1989 \\
\hline \multirow[t]{3}{*}{ R. limnocharis } & - & - & $27.1^{*}$ & - & 170 & 667 & China & Liu and Chen, 1933 \\
\hline & $40.0-62.3$ & 51.8 & 27.9 & 4.7 & 56 & 337 & Sigapore & Berry, 1965 \\
\hline & $21-44$ & - & 13.5 & - & 25 & 51 & India & Mohanty-Hejmadi and Acharya, 1982 \\
\hline R. macrodon & $<128$ & 14 & 12 & - & 50 & 133 & Sarawak & Inger and Greenberg, 1966 \\
\hline R. namiyei & $30-110$ & - & $0-1.7$ & $0-18.2$ & 32 & 77 & Japan & Okochi and Katsuren, 1989 \\
\hline R. narina & $10-80$ & - & $1.7-8.4$ & $11.1-33.3$ & 77 & 161 & Japan & Okochi and Katsuren, 1989 \\
\hline \multirow[t]{5}{*}{ R. nigromaculata } & $a-$ & - & $15.1^{*}$ & - & 50 & 119 & China & Liu and Chen, 1933 \\
\hline & $<40$ & 75.0 & 45.4 & - & 28 & 194 & Japan & Hirai and Matsui, 1999 \\
\hline & $40-55.9$ & 26.2 & 12.3 & - & 42 & 349 & Japan & Hirai and Matsui, 1999 \\
\hline & $56<$ & 30.4 & 19.2 & - & 46 & 229 & Japan & Hirai and Matsui, 1999 \\
\hline & $19-90.3$ & 42.7 & 20.3 & 1.2 & 475 & 3693 & Japan & Hirai and Matsui, 1999 \\
\hline R. pipiens & - & 5.8 & 0.4 & - & 433 & 12396 & Florida & Kilby, 1945 \\
\hline
\end{tabular}


Appendix 1. (cont.)

\begin{tabular}{|c|c|c|c|c|c|c|c|c|}
\hline \multirow{2}{*}{ Species } & \multirow{2}{*}{$\begin{array}{l}\text { Size }(\mathrm{mm}) \\
\quad \text { or sex }\end{array}$} & \multicolumn{3}{|c|}{ Proportion (\%) } & \multicolumn{2}{|c|}{ Sample size } & \multirow{2}{*}{ Locality } & \multirow{2}{*}{ Authority } \\
\hline & & $\mathrm{F}$ & $\mathrm{N}$ & $\mathrm{V}$ & Frog & Prey & & \\
\hline & $27-58$ & 28.4 & - & 4 & 95 & - & New York & Whitaker, 1962 \\
\hline & - & $45^{\star}$ & 4.3 & - & 20 & 184 & Canada & Moore and Strickland, 1954 \\
\hline & $27-58$ & 28.4 & - & 4 & 95 & - & New York & Whitaker, 1962 \\
\hline & $20-35$ & 14.2 & - & 2.9 & - & - & New York & Linzey, 1967 \\
\hline & $50-80$ & 15.3 & - & 0.9 & - & - & New York & Linzey, 1967 \\
\hline & - & 60.9 & 14.8 & - & 23 & 162 & Minnesota & Hedeen, 1972 \\
\hline & - & 33.3 & - & - & 6 & - & Nebraska & Frederick and Collette, 1959 \\
\hline & - & - & 6.2 & - & 50 & 373 & Montana & Miller, 1977 \\
\hline R. pirica & - & - & 1.1 & - & 50 & 281 & Japan & Inukai, 1925 \\
\hline \multirow[t]{6}{*}{ R. pretiosa } & - & $<27.5$ & - & - & 142 & - & Wyoming & Turner, 1959 \\
\hline & - & 24.3 & - & 4.4 & 206 & - & Oregon & Whitaker et al., 1983 \\
\hline & $28-33$ & 16.7 & 6 & - & 18 & 116 & Canada & Licht, 1986 \\
\hline & $>40$ & 26.1 & 3.7 & - & 23 & 191 & Canada & Licht, 1986 \\
\hline & - & 22.0 & 4.6 & - & 41 & 307 & Canada & Licht, 1986 \\
\hline & - & - & 19.3 & - & 50 & 517 & Montana & Miller, 1977 \\
\hline R. rugosa & $24.6-58.1$ & $81.9-85.7$ & $56.8-59.4$ & $4.1-13.2$ & $14-72$ & $262-1577$ & Japan & This study \\
\hline \multirow[t]{3}{*}{ R. septentrionalis } & - & $27.0^{*}$ & - & $2.4^{*}$ & 159 & 2503 & New York & Kramek, 1972 \\
\hline & - & 28.0 & - & 3.8 & - & - & New York & Stewart and Sandison, 1972 \\
\hline & - & $10.5-52.2$ & $1.2-6.8$ & - & $18-23$ & $234-1421$ & Minnesota & Hedeen, 1972 \\
\hline \multirow[t]{6}{*}{ R. temporaria } & - & 2 & 0.1 & $<0.1$ & 359 & 6681 & England & Houston, 1973 \\
\hline & - & $29^{*}$ & $6^{*}$ & - & 70 & - & Ireland & Blackith and Speight, 1974 \\
\hline & $<30$ & - & $<15^{*}$ & - & $58-194$ & - & Sweden & Loman, 1979 \\
\hline & $30-47$ & - & $<5^{*}$ & - & $46-89$ & - & Sweden & Loman, 1979 \\
\hline & - & - & 0.4 & - & 17 & 228 & England & Savage, 1961 \\
\hline & - & - & 10.1 & - & 30 & 503 & France & Pilorge, 1982 \\
\hline R. tigerina & $100-143$ & $<10$ & - & - & 819 & - & Pakistan & Khan, 1973 \\
\hline R. vaillanti & - & 0 & 0 & - & 819 & - & Mexico & Ramirez et al., 1998 \\
\hline
\end{tabular}

$+=$ Unspecified small amount

${ }^{*}=$ Proportion of Hymenoptera 